Reprod. Nutr. Dévelop., 1982, 22 (5), 793-801.

\title{
The influence of nutritional levels and shade structure on testicular growth and hourly variations of plasma LH and testosterone levels in young Creole bulls in a tropical environment
}

\author{
D. GAUTHIER, P. BERBIGIER (*)
}

with the technical assistance of A. CARATY $\left(^{* *}\right)$ and F. FOULON $\left(^{* *}\right)$

Station de Recherches zootechniques

(*) Station de Bioclimatologie

Domaine Duclos, C.R.A.A.G., I.N.R.A., 97170 Petit Bourg, France.

(**) Station de Physiologie de la Reproduction I.N.R.A., Nouzilly 37380 Monnaie.

Summary. Twelve Creole bulls 13.3 months of age were divided into three groups according to live weight. The first group received a low nutritional level and was housed in a shaded stable; the second group received a high nutritional level and was housed in the same stable as the first group; the third group received the same ration as the second group but was exposed to solar radiation. Live weight and testicular diameter were recorded fortnightly.

After 65 days, the blood of the bulls was sampled every 20 min for $12 \mathrm{~h}$. Plasma LH and testosterone were quantified by radioimmunoassay.

There was no significant influence of solar radiation on the testicular growth or the hormonal levels. Underfeeding decreased testicular growth and the average plasma $\mathrm{LH}$ and testosterone levels. However, this action was effective only in decreasing the number of hormonal pulses per day ( 0.63 vs 2.55 LH pulses per day and 0.75 vs 2.50 testosterone pulses per day) ; it did not change the basal hormone levels.

It is suggested that this decrease in LH pulsatility might be responsible for the slow testicular growth in the underfed bulls.

\section{Introduction.}

A low-quality diet delays puberty in males (Rattray, 1977). First ejaculation occurs at the age of 52 weeks in Holstein bulls fed at 60 p. 100 of the recommanded TDN for maintenance and at 45 weeks in bulls fed a 100 p. 100 level (Van Demark and Mauger, 1964). Hormonal concentrations may by involved.

Underfeeding induces a low plasma gonadotrophin level in cows (Terqui et al., 1981) and decreases the testicular testosterone content (Mann et al., 1967) in 
bulls. However, LH and testosterone are released in the blood in a pulsatile pattern (Lacroix and Pelletier, 1979 ; Terqui et al., 1980), and it is not known if underfeeding affects the basal levels or the pulsatile frequencies.

High temperatures delay puberty in terms of sperm production (de Alba and Riera, 1966 ; Ortavant and Loir, 1978). This detrimental effect is related to the increase of testicular temperature (Ortavant and Loir, 1978). The influence of high temperature on hormonal concentrations and its relation to testicular growth have never been investigated.

A low-quality diet and high temperatures are the main factors involved in the poor yield of cattle in tropical countries. The aim of this work was to study the influences of underfeeding and solar exposure during the pubertal period on testicular growth and the hourly variations of plasma $\mathrm{LH}$ and testosterone levels of Creole bulls in a tropical environment.

\section{Material and methods.}

Twelve immature Creole Bulls 13.3 months of age were started on trial in February (dry season) at the Gardel experimental farm of the INRA (Guadeloupe, French West Indies). The bulls were assigned to three treatment groups according to live weight. Group 1 received a low nutritional level and groups 2 and 3 received high levels. The rations are described on table 1. Groups 1 and 2 were housed in a shaded stable and group 3 was exposed to solar radiation.

Meteorological data for the experimental period are shown in table 2. Maximal and minimal air temperatures, relative humidity and global solar radiation were recorded daily at a meteorological station situated $2 \mathrm{~km}$ from the farm. The windspeed was measured at animal level with cup anemometers (starting threshold : $0.8 \mathrm{~m} / \mathrm{s}$ ). The rainfall was also recorded at the experimental site.

The rectal temperatures and respiratory rates of the animals were measured 12 times (twice a week for 6 weeks) at $11.00,13.00$ and $15.00 \mathrm{~h}$, and their cardiac rates were also measured at $13.00 \mathrm{~h}$ on the same days.

Black globe (12-cm diameter) temperature, which provides an estimation of the temperature felt by a non-sweating animal, was measured at animal levels at $13.00 \mathrm{~h}$ for 11 of the 12 days mentioned above. The results were $28.4 \pm 1.2^{\circ} \mathrm{C}$ in the stable and $37.1 \pm 2.7^{\circ} \mathrm{C}$ in direct sunshine.

TABLE 1

Daily rations of the two feeding levels ( $\mathrm{kg}$ of dry matter).

\begin{tabular}{lcc}
\hline & $\begin{array}{c}\text { High level } \\
\text { (Groups 2 and 3) }\end{array}$ & $\begin{array}{c}\text { Low level } \\
\text { (Group 1) }\end{array}$ \\
\hline Forage (Digitaria decumbens) $\ldots \ldots$ & 1 & 2.4 \\
Concentrate $\ldots \ldots \ldots \ldots \ldots \ldots \ldots$ & 4.3 & 1.9 \\
\hline
\end{tabular}

The concentrate contained : urea 5 p. 100 , molasses 10 p. 100 , wheat bran 65.5 p. 100 , corn 17.5 p. 100 , minerals and salt 2 p. 100. 


\section{TABLE 2}

Meteorological data (daily average over 64 days) $(m \pm$ SEM).

\begin{tabular}{|c|c|c|c|c|c|c|}
\hline $\begin{array}{l}\text { Temperature } \\
\text { maximum } \\
\left({ }^{\circ} \mathrm{C}\right)\end{array}$ & $\begin{array}{l}\text { Temperature } \\
\text { minimum } \\
\left({ }^{\circ} \mathrm{C}\right)\end{array}$ & $\begin{array}{c}\text { Relative } \\
\text { humidity } \\
\text { maximum } \\
(\text { p. 100) }\end{array}$ & $\begin{array}{l}\text { Relative } \\
\text { humidity } \\
\text { minimum } \\
\text { (p. 100) }\end{array}$ & $\begin{array}{c}\text { Global } \\
\text { radiation } \\
\left(10^{6} \mathrm{~J} / \mathrm{m}^{2} \times \text { day }\right)\end{array}$ & $\begin{array}{l}\text { Windspeed } \\
\text { (ms) }\end{array}$ & $\begin{array}{l}\text { Rainfall } \\
\text { (mn/day) }\end{array}$ \\
\hline $\begin{array}{r}28.45 \\
\pm 0.06\end{array}$ & $\begin{array}{r}21.97 \\
\pm 0.17\end{array}$ & $\begin{array}{r}94.1 \\
\pm 0.7\end{array}$ & $\begin{array}{r}67.1 \\
\pm 0.9\end{array}$ & $\begin{array}{r}21.0 \\
\pm 0.3\end{array}$ & $\begin{array}{c}\text { Inside } \\
1.35 \\
\text { Outside(*) } \\
<0.80\end{array}$ & 0.75 \\
\hline
\end{tabular}

$(*)$ The recorded value of windspeed for animals outdoors is low as they faced the direction of the tradewinds and were shielded to protect their food from the rair.

The bulls were weighed fortnightly, and the antero-posterior diameter of each testicle was recorded using a calipers each time. This provided a good prediction of testicular weight (Coulter and Foote, 1979). Sixty-five days after the beginning of the experiment, when the average testicular diameters of the three groups were equivalent, the blood of the bulls was sampled by jugular venipuncture every $20 \mathrm{~min}$ for $12 \mathrm{~h}$; it was centrifuged immediately at $4{ }^{\circ} \mathrm{C}$ and the plasma stored at $-15^{\circ} \mathrm{C}$ until $\mathrm{LH}$ and testosterone assays. The rectal temperature and respiratory rate were measured on the same day at $08.00,11.00$, 14.00 and $17.00 \mathrm{~h}$.

Plasma LH and testosterone levels were measured by specific radioimmunoassays (LH : Pelletier, 1972 ; testosterone: Garnier, Cotta and Terqui, 1978, modified by $\mathrm{N}$-acetyl-cyclo-hexane extraction). We considered and $\mathrm{LH}$ or testosterone value as a pulse when it was greater than the mean + 2 SEM level encountered during the 12 hrs sampling period and was followed by at least one lower value which was still elevated above the mean concentration.

On the same animals, repeated measurements (rectal, temperature, respiratory and cardiac rates, average and basal levels of $\mathrm{LH}$ and testosterone) were analyzed by split-plot analysis of variance (Gill and Hafs, 1971). Average daily weight gain, increase in testicular diameter and the number of hormonal pulses per day, variables with an unknown distribution and a few data were analyzed by the rank-test of Mann and Whitney (Snedecor and Cochran, 1971).

\section{Results.}

\section{1) Heat regulation parameters.}

Within-group. Neither the time of day nor the day of measurement had any effect on the three parameters studied, i.e. rectal temperature, respiratory rate and cardiac rate. Therefore, the general average of each group was used.

Between-group. The rectal temperature and the cardiac rate were not different among the three groups. The respiratory rate was lower in group 1 than in groups 2 and $3(P<0.05)$ (table 3$)$. On the day of blood sampling, the rectal 
TABLE 3

Rectal temperature, respiratory rate and cardiac rate during the experiment according to group $(\mathrm{m} \pm \mathrm{SEM})$

\begin{tabular}{lccc}
\hline & $\begin{array}{c}\text { Group 1 } \\
\text { (low level and shade) }\end{array}$ & $\begin{array}{c}\text { Group 2 } \\
\text { (high level and shade) }\end{array}$ & $\begin{array}{c}\text { Group 3 } \\
\text { (high level and sun) }\end{array}$ \\
\hline Rectal temperature $\left({ }^{\circ} \mathrm{C}\right)$ & $39.0^{\mathrm{a}} \pm 0.1$ & $39.1^{\mathrm{a}} \pm 0.1$ & $39.1^{\mathrm{a}} \pm 0.1$ \\
\hline $\begin{array}{l}\text { Respiratory rate } \\
\text { (counts } / \mathrm{min}) \ldots \ldots \ldots\end{array}$ & $24.1^{\mathrm{a}} \pm 1.3$ & $30.7^{\mathrm{b}} \pm 1.8$ & $32.8^{\mathrm{b}} \pm 1.5$ \\
\hline Cardiac rate $($ counts $/ \mathrm{min})$ & $98.6^{\mathrm{a}} \pm 5.6$ & $107.3^{\mathrm{a}} \pm 6.1$ & $105.8^{\mathrm{a}} \pm 5.4$ \\
\hline
\end{tabular}

Parameter values with the same superscript were not significantly different at $P<0.05$.

temperature and respiratory rate were similar to those recorded on other days. The sampling itself had no effect on these parameters.

2) Live weight variations. - During experimentation, the average live weights of groups 1,2 and 3 increased from $163 \pm 8.4,156 \pm 6.6$ and $155 \pm 4.2$ to $187 \pm 6.7,207 \pm 8.9$ and $200 \pm 6.4 \mathrm{~kg}$, respectively. The average daily gain was significantly lower for group 1 (370 g) than for groups 2 and 3 (780 and $690 \mathrm{~g}$, respectively ; $\mathrm{P}<0.01$ ).

3) Testicular growth. - The total increase in testicular diameter in groups 1 , 2 and 3 during the experiment was $6.75,13.03$ and $11.0 \mathrm{~mm}$, respectively. The average daily increase in testicular diameter was $0.10,0.20$ and $0.17 \mathrm{~mm}$, respectively, for the three groups. Group 1 had lower testicular growth than groups 2 and $3(P<0.05)$.

The testicular diameter in each group was correlated to the logarithm of the live weight. The regressions of testicular diameter on the logarithm of the live weight were not different among the three groups (table 4).

4) Plasma $L H$ Level. - LH was released in the blood in a pulsatile pattern (fig. 1). The number of pulses occuring during a 12-hr period varied from 0 to 4 , depending on the animal. From an average basal level of $2 \mathrm{ng} / \mathrm{ml}$, the plasma $\mathrm{LH}$ level increased rapidly to a mean level of $7 \mathrm{ng} / \mathrm{ml}(3-12 \mathrm{ng} / \mathrm{ml})$, then decreased slowly during an average LH pulse (total duration : about $60 \mathrm{~min}$ ).

\section{TABLE 4}

Regression of testicular diameter on live weight according to group.

\begin{tabular}{ccc}
\hline Groups & Equation & Correlation \\
\hline 1 & $Y=33.3 \log X-130.5$ & $r=0.76$ \\
2 & $Y=28.2 \log X-110.34$ & $r=0.84$ \\
3 & $Y=35.7 \log X-148.24$ & $r=0.69$ \\
\hline
\end{tabular}

(The differences between the different parameters are not significant). 


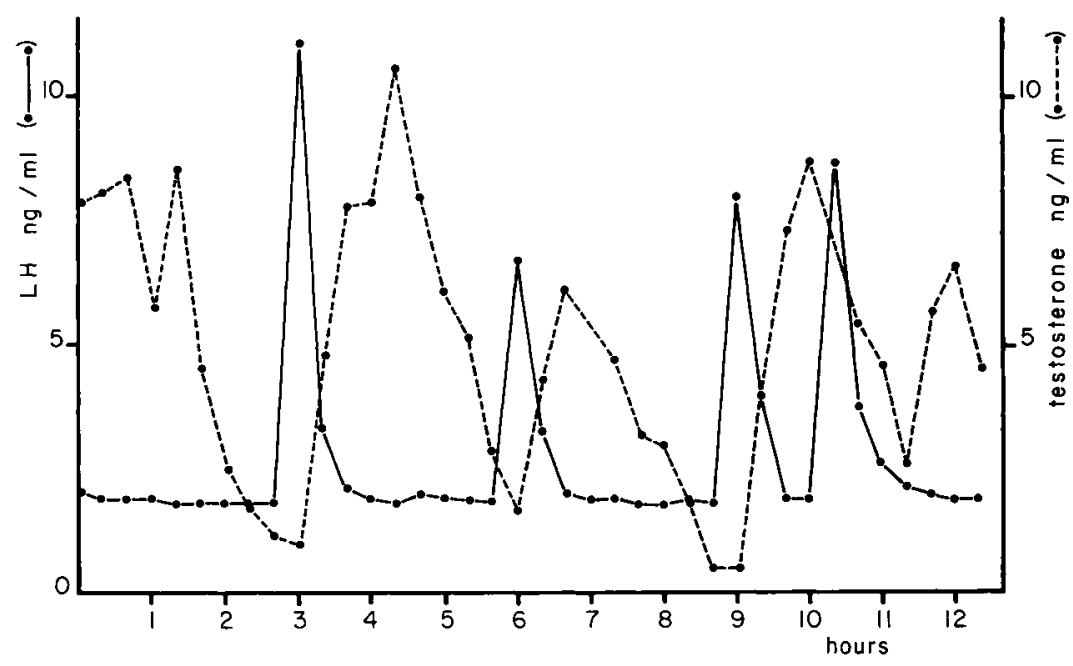

FIG. 1. - Peripheral blood concentrations of $L H$ and testosterone over 12-hour periods in one representative bull.

The average plasma LH level was higher in group 2 than in group $1(2.57$ vs $2.11 ; P<0.05$ ). There was no difference between groups 2 and 3 (table 5). However, the basal level was almost the same in the three groups $11.88,2.05$ and $2.0 \mathrm{ng} / \mathrm{ml}$, respectively ; table 5). The number of LH pulse per day was higher in groups 2 and 3 than in group $1(2.25,1.75$ vs $0.63 ; P<0.05)$ and not significantly different between groups 2 and 3 (table 5). The magnitude of LH pulses in group 2 seemed to be higher than in group $3(7.76 \pm 1.31 \mathrm{vs}$ $5.60 \pm 0.96 \mathrm{ng} / \mathrm{ml})$ but the difference was not significant $(P<0.07)$. Group 1 did not have enough pulses to estimate an average magnitude. The number of $\mathrm{LH}$ pulses per day was highly correlated to the live weight and to the average daily gain $(r=0.78$ and 0.82 , respectively ; $P<0.01)$.

TABLE 5

$\mathrm{LH}$ and testosterone parameters according to group $(\mathrm{m} \pm \mathrm{SEM}$ ).

\begin{tabular}{|c|c|c|c|c|c|c|c|c|}
\hline \multirow{3}{*}{$\begin{array}{c}\text { Groups } \\
1\end{array}$} & \multirow{2}{*}{\multicolumn{2}{|c|}{$\begin{array}{c}\text { Average level } \\
\mathrm{LH} \quad \text { Testosterone }\end{array}$}} & \multicolumn{2}{|c|}{ Number of pulses } & \multicolumn{2}{|c|}{ Magnitude of pulses } & \multicolumn{2}{|c|}{ Base level } \\
\hline & & & & ssterone & LH T & osterone & LH & ssterone \\
\hline & $\begin{aligned} & 2.11^{\mathrm{a}} \\
- & 0.08\end{aligned}$ & $\begin{aligned} & 1.19^{\mathrm{a}} \\
+ & 0.14\end{aligned}$ & $\begin{aligned} & 0.63^{\mathrm{a}} \\
\pm & 0.24\end{aligned}$ & $\begin{aligned} & 0.75^{\mathrm{a}} \\
\pm & 0.30\end{aligned}$ & * & * & $\begin{array}{ll} & 1.88^{\mathrm{a}} \\
+ & 0.05\end{array}$ & $\begin{aligned} & 0.48^{\mathrm{a}} \\
\pm & 0.09\end{aligned}$ \\
\hline 2 & $\begin{aligned} & 2.57^{\mathrm{b}} \\
\pm & 0.15\end{aligned}$ & $\begin{aligned} & 2.64^{\mathrm{b}} \\
\pm & 0.80\end{aligned}$ & $\begin{aligned} & 2.25^{b} \\
\pm & 0.63\end{aligned}$ & $\begin{aligned} & 2.50^{\mathrm{b}} \\
\pm & 0.24\end{aligned}$ & $\begin{array}{l}7.76^{\mathrm{a}} \\
1.31\end{array}$ & $\begin{array}{l}7.54 \\
1.50\end{array}$ & $\begin{aligned} & 2.05^{\mathrm{a}} \\
\pm & 0.15\end{aligned}$ & $\begin{aligned} & 0.33^{\mathrm{a}} \\
\pm & 0.06\end{aligned}$ \\
\hline 3 & $\begin{array}{ll} & 2.33^{\text {ba }} \\
\pm & 0.12\end{array}$ & 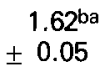 & $\begin{array}{ll} & 1.75^{\mathrm{b}} \\
\pm & 0.25\end{array}$ & $\begin{aligned} & 1.75^{b} \\
\pm & 0.25\end{aligned}$ & $\begin{array}{r}5.6^{\mathrm{b}} \\
\pm 0.96\end{array}$ & $\begin{array}{r}6.63 \\
+1.10\end{array}$ & $\begin{aligned} & 2.00^{\mathrm{a}} \\
\pm & 0.11\end{aligned}$ & $\begin{aligned} & 0.40^{\mathrm{a}} \\
\pm & 0.04\end{aligned}$ \\
\hline
\end{tabular}

Parameter values with the same superscript were not significantly different at $P<0.05$.

${ }^{*}$ ) Group 1 did not have enough pulses to estimate a magnitude. 
5) Plasma testosterone level. - Testosterone was released in a pulsatile pattern, an increase in plasma testosterone occurring after each $\mathrm{LH}$ pulse. In the first sample after the LH peak, testosterone concentration began to increase in the plasma from a basal level of $0.4 \mathrm{ng} / \mathrm{ml}$ to an average level of $7 \mathrm{ng} / \mathrm{ml}$ $(4-10 \mathrm{ng} / \mathrm{ml}$ ). The increase was less rapid than that of $\mathrm{LH}$, and $60 \mathrm{~min}$ elapsed between the beginning of testosterone increase and the onset of its decrease. The total testosterone pulse lasted about $2 \mathrm{~h}$ (fig. 1).

Average plasma testosterone levels were higher in group 2 than in group 1 $(2.65$ vs $1.19 \mathrm{ng} / \mathrm{ml} ; \mathrm{P}<0.05)$. The plasma testosterone levels of group 2 seemed to be higher than those of group 3 , but the difference was not significant (table 5). Basal levels of testosterone were not different among the 3 groups.

The number of testosterone pulses was lower in group 1 than in group 2 (2.5 vs 0.75 pulses/day ; $\mathrm{P}<0.05)$ and not different between groups 2 and 3 (2.5 vs 1.75 pulses/day) (table 5). There was no difference in response time, ie the time between the LH pulse and the testosterone pulse, or in the response magnitude among the three groups.

\section{Discussion.}

The difference in growth among the groups of Creole bulls indicates that we obtained two real distinct nutritional groups and that a difference in growth (370 g/day vs $780 \mathrm{~g} /$ day) can induce a difference in testicular growth and probably in the onset of puberty. It is interesting to note that testicular growth according to live weight is constant, whatever the feeding level.

The results of underfeeding in the Creole bulls observed here, ie an induced decrease in the plasma gonadotrophin level, confirm the work of earlier investigators using male and female rats (Campbell et al., 1977 ; Blask et al., 1980) and cows (Terqui et al., 1981). Thus, underfeeding constitutes a " pseudohypophysectomy " (Mulinos and Pomerantz, 1940), leading to a decrease in testicular growth similar to that in rat (Sorrentino, Reiter and Schalch, 1971).

Underfeeding does not change the basal LH level. The low average LH level proceeds solely from weak pulsatility. As for the other physiological states, the regulation of LH levels is achieved by a frequency modulation of the pulsatility during photo-periodic regulation (Lincoln et al., 1977 ; Terqui et al., 1980), postpartum anoestrus (Gayerie, Cognié and Locatelli, 1980) or prior to puberty (Lacroix and Pelletier, 1979).

The modulation of amplitude and frequency changes in pulsatile gonadotrophin release is probably governed by the activity of neurons discharging $\mathrm{GnRH}$. These conclusions are based on the observation that passive immunization with $\mathrm{GnRH}$ antibodies evokes an immediate blockade in episodic LH secretion (Lincoln, 1979 ; Lincoln and Fraser, 1979).

Physiologically, LH pulsatility is low when pituitary sensitivity to $\mathrm{GnRH}$ is also low (postpartum anoestrus : Terqui et al., 1981). But, the secretory LH response of the pituitary to a synthetic $\mathrm{GnRH}$ injection is greater in diet-deficient animals than in those with a control diet (rat : Campbell et al., 1977 ; cattle : Beal et al., 
1978; Gauthier and Mauléon, unpublished data). Thus, the low pulsatility observed in underfed animals is a direct result of nutritional deprivation on hypothalamic function rather than a defect in pituitary physiologi per se.

As the $\mathrm{LH}$ level, the average plasma testosterone level in decreased through underfeeding. This decrease is due to weak testosterone pulsatility, the basal level remaining unchanged.

Testosterone pulses are the testicular endocrine response to the $\mathrm{LH}$ pulse (Thibier, 1977 ; Terqui et al., 1980) and testicular sensitivity to LH secretion, in terms of testosterone response, seems unchanged. Thus, low testosterone pulsatility appears to be due only to weak LH pulsatility.

Temperature is known to reduce testicular weight and testicular endocrine functions (Gomes, Butler and Johnson, 1971 ; Rhynes and Ewing, 1973). In our study, however, the effect of solar radiation had no effect on the $\mathrm{LH}$ and testosterone pattern or on testicular growth.

These results are not surprising since, even when the bulls of temperate countries (Hereford) are submitted to heat stress, plasma testosterone concentrations return to normal levels after 7 weeks (Rhynes and Ewing, 1973). Furthermore, the Creole breed bull has a low sensitivity to heat. This is confirmed by the lack of difference in rectal temperature, respiratory rate and cardiac rate between animals when shaded or not.

Reçu en décembre 1981. Accepté en avril 1982.

Résumé. Douze taurillons créoles immatures, âgés de 13,3 mois en moyenne, sont répartis en 3 lots selon leur poids vif. Le premier lot recoit un bas niveau d'alimentation et est maintenu à l'attache dans un local abrité, le second placé dans la même étable reçoit un niveau alimentaire élevé, quant au troisième, il reçoit la même ration que le second mais il est exposé à l'extérieur sans protection. Le poids et le diamètre testiculaire des animaux sont enregistrés tous les 14 jours.

Après 65 jours d'expérience, des échantillons sanguins sont prélevés toutes les $20 \mathrm{~min}$ pendant $12 \mathrm{~h}$ dans la veine jugulaire des taureaux afin de doser la $\mathrm{LH}$ et la testostérone plasmatiques.

II n'y a aucune influence de l'ensoleillement ni sur les croissances corporelle et testiculaire, ni sur les niveaux hormonaux. Outre son influence sur la croissance corporelle, la sous alimentation entraîne une diminution de la croissance testiculaire et des niveaux moyens de LH et de testostérone, sans changement du niveau de base, mais par le biais de la diminution du nombre de pulses en $12 \mathrm{~h}$.

Il semble donc que la diminution du nombre de pulses de LH soit responsable de la croissance testiculaire lente chez les animaux moins bien alimentés.

\section{Références}

BEAL W. E., SHORT R. E., STAIGMILLER R. B., BELLOWS R. A., KALTENBACH C.C., DUNN T. G., 1978. Influence of dietary energy intake on bovine pituitary and luteal function. J. anim. Sci, 46, 181-188.

BLASK D. E., NODELMA J. L., LEADEM C. A., RICHARDSON B. A., 1980. Influence of exogenously administered melatonin on the reproductive system and prolactin levels in underfed male rats. Biol. Reprod., 22, 507-512. 
CAMPBELL G. A., KURCZ M., MARSHALL S., MEITES J., 1977. Effects of starvation in rats on serum levels of follicle-stimulating hormone, luteinizing hormone, thyrotropin, growth hormone and prolactin; responses to LH - releasing hormone and thyrotropin - releasing hormone. Endocrinology, 100, 580-587.

COULTER G. H., FOOTE R. H., 1979. Bovine testicular measurements as indicators of reproductive performance and their relationship to productive trait in cattle : a review. Theriogenology, 11, 297-311.

DE ALBA J., RIERA S., 1966. Sexual maturity and spermatogenesis under heat stress in the bovine. Anim. Prod., 8, 137-144.

GARNIER D. H., COTTA Y., TERQUI M., 1978. Androgen radioimmunoassay in the ram : results of direct plasma testosterone and dehydroepiandrosterone measurement and physiological evaluation. Ann. Biol. anim. Biochim. Biophys., 17, 265-281.

GAYERIE F., COGNIE Y., LOCATELLI A., 1980. Pituitary and ovarian activity before and after PMSG in " lle de France » ewes after autumn (A) and spring (S) lambing. 9th int. Congr. anim. Reprod. art. Insem., Madrid, III, 108.

GILL J. L., HAFS H. D., 1971. Analysis of repeated measurements of animals. J. anim. Sci., 33 , 331-340.

GOMES W. R., BUTLER W. R., JOHNSON A. D., 1971. Effect of elevated ambient temperature on testis and blood levels and " in vitro" biosynthesis of testosterone in the ram. J. anim. Sci., 33, 804-807.

LACROIX A., PELLETIER J., 1979. Short-term variations in plasma LH and testosterone in bull calves from birth to 1 year of age. J. Reprod. Fert., 55, 81-85.

LINCOLN G. A., 1979. Use of a pulsed infusion of luteinizing hormone releasing hormone to mimic seasonally induced endocrine changes in the ram. J. Endocr., 83, 251-260.

LINCOLN G. A., FRASER H. M., 1979. Blockade of episodic secretion of luteinizing hormone in the ram by the administration of antibodies to luteinizing hormone-releasing hormone. Biol. Reprod., 21, 1239-1245.

LINCOLN G. A., PEET M. J., CUNNINGHAM R. A., 1977. Seasonal and circadian changes in the episodic release of follicle-stimulating hormone, luteinizing hormone and testosterone in ram exposed to artificial photoperiods. J. Endocr. 72, 337-349.

MAN T., ROWSON L. E. A., SHORT R. V., SKINNER J. D., 1967. The relationship between nutrition and androgenic activity in pubescent twin calves and the effect of orchitis. $J$. Endocr., 38, 155-168.

MULINOS M. G., POMERANTZ L., 1940. Pseudo-hypophysectomy: a condition resembling produced by malnutrition. J. Nutr., 19, 493-504.

ORTAVANT R., LOIR M., 1978. The environment as a factor in reproduction in farm animals. World Congr. anim. Product, Buenos Aires, August 1978 (in press).

PELLETIER J., 1972. Dosages radioimmunologiques de la LH plasmatique ovine et bovine, 237-255. In Techniques radioimmunologiques. INSERM ed., Paris.

RATTRAY P. V., 1977. Nutrition and reproductive efficienty, 553-575. In COLE H. H., CUPPS P. T., Reproduction in domestic animals. Acad. Press, New-York.

RHYNES W. E., EWING L. L., 1973. Testicular endocrine function in Hereford bulls exposed to high ambient temperature. Endocrinology, 92, 509-515.

SNEDECOR G. W., COHRAN W. G., 1971. Méthodes statistiques. Traduction de Statistical methods. 6th éd., A.C.T.A. éd., Paris.

SORRENTINO S., REITER R. J., SCHALCH D. S., 1971. Interactions of the pineal gland blinding and underfeeding on respective organ size and radio-immunoassayable growth hormone. Neuroendocrinology, 7, 105-115.

TERQUI M., GARNIER D. H., de REVIERS M.M., HUET S., PELLETIER J., 1980. La structure chronologique du dialogue entre l'hypophyse et les gonades chez les mammifères domestiques, 59-72. In R. ORTAVANT, A. REINBERG, Rythmes et Reproduction. Masson et Cie, Paris.

TERQUI M., CHUPIN D., GAUTHIER D., PEREZ N., PELOT J., MAULEON P., 1981. Influence of management and nutrition on post-partum endocrine function and ovarian activity in cows. Congr. C.E.E. Munich (in press). 
THIBIER M., 1977. Contribution à l'étude de la fonction sexuelle chez le jeune taurillon. Th. Doct. Etat, Univ. P. et M. Curie (Paris $\left.6^{\circ}\right)$.

VAN DEMARK N. L., MAUGER R. E., 1964. Effect of energy intake on reproductive performance of dairy bulls. I. Growth, of reproductive organs, and puberty. J. Dairy Sci., 47, 792-802. 